\title{
Chemopreventive effect of Copaifera langsdorffii leaves hydroalcoholic extract on 1,2-dimethylhydrazine-induced DNA damage and preneoplastic lesions in rat colon
}

Juliana Marques Senedese ${ }^{1}$, Jacqueline Morais Alves', Ildercílio Mota de Souza Lima1', Erick Augusto Pedroso de Andrade1, Ricardo Andrade Furtado², Jairo Kenupp Bastos ${ }^{2}$ and Denise Crispim Tavares ${ }^{1 *}$

\begin{abstract}
Background: Natural antioxidants present in common foods and beverages have drawn great attention to cancer prevention due to its health benefits, remarkable lack of toxicity and side effects. Copaifera langsdorffii, known as "copaiba", "capaiva", or "pau-de-óleo", belongs to the Leguminosae family and occurs in fields and grasslands in the northern and northeastern parts of Brazil. Biological studies of Copaifera corroborate its widespread use by the population. This paper describes the effects of $C$. langsdorffii leaves hydroalcoholic extract on the 1,2-

dimethylhydrazine (DMH)-induced DNA damage and aberrant crypt foci (ACF) in the colon of male Wistar rats.

Methods: The hydroalcoholic extract of C. langsdorffii was administered to rats by gavage at daily doses of 20, 40 and $80 \mathrm{mg} / \mathrm{kg}$ body weight. To evaluate DNA damage by the comet assay, animals received the $C$. langsdorffii extract for seven days and a single subcutaneous injection (sc) of 1,2-dimethylhydrazine (DMH) at a dose of $40 \mathrm{mg} / \mathrm{kg}$ on day 7. Animals were sacrificed $4 \mathrm{~h}$ after injection of DMH, to assess DNA damage. For the ACF assay, animals were acclimatized for one week (week 1) and then treated with the C. langsdorffii extract five times a week for four weeks (weeks 2 to 5). The rats received sc injections of DMH (40 mg/kg) on days 2 and 5 of weeks 2 and 3, to induce ACF. Animals were euthanized at week 5; i.e., four weeks after the first DMH treatment.

Results: Animals treated with different doses of the C. langsdorffii extract combined with DMH had significantly lower frequency of DNA damage as compared with the positive control (animals treated with DMH only). The percentage of reduction in the frequency of DNA damage ranged from $14.30 \%$ to $38.8 \%$. The groups treated with 40 and $80 \mathrm{mg} / \mathrm{kg}$ C. langsdorffii extract during and after DMH treatment presented significantly lower numbers of ACF and aberrant crypts compared with the control.
\end{abstract}

Conclusion: The C. langsdorffii extract significantly reduced the extent of DNA damage and ACF induced by DMH, suggesting that the extract has a protective effect against colon carcinogenesis.

Keywords: Copaifera langsdorffii, Comet assay, Aberrant crypt foci.

\footnotetext{
*Correspondence: denisecrispim2001@yahoo.com

${ }^{1}$ Avenida Dr. Armando Salles de Oliveira, Universidade de Franca, 201 Parque Universitário, Franca, São Paulo 14404-600, Brazil

Full list of author information is available at the end of the article
} 


\section{Background}

Colorectal cancer is a major cause of death; its incidence is increasing worldwide [1]. Genetic susceptibility and diet determine cancer risk and tumor behavior [2]. Experimental studies have suggested that plant food components can suppress cancer development through a variety of different mechanisms [3]. Chemoprevention is defined by the use of natural, synthetic, biological, or chemical agents that can reverse, suppress, or prevent carcinogenesis [4].

Plants produce a conspicuous structural diversity of metabolites and represent the largest source of active compounds; they are perhaps the earliest source of drugs for human use [5]. Copaifera langsdorffii, popularly known as "copaiba", "copaíva", or "pau-de-óleo", belongs to the family Leguminosae and occurs in fields and grasslands in northern and northeastern Brazil. The $C$. langsdorffii oil-resin is a folk remedy in its natural form and presents several biological activities such as antiparasitic action against Leishmania amazonensis [6] as well as antinociceptive [7], anti-inflammatory [8], analgesic [8], diuretic $[9,10]$, antitumoral [11], antiulcerogenic [12], anti-lipoperoxidation [13], and antioxidant [13] effects.

In this paper we report the chemopreventive potential of the hydroalcoholic extract of $C$. langsdorffii leaves in the colon of male Wistar rats. Researchers have developed several experimental animal models of colon carcinogenesis, to screen chemopreventive agents against colon cancer. Colon carcinogenesis induced by 1,2-dimethylhydrazine $(\mathrm{DMH})$ is histologically, morphologically, and anatomically similar to human colonic epithelial neoplasms [14]. Preneoplastic lesions of the colonic mucosa, the aberrant crypt foci (ACF), are one of the early morphological changes on the DMH-stimulated colonic mucosal surface in rodents [15].

Since it has been indicated that the induction of ACF is clearly related to genotoxic events, primary DNA damage in colon cells is an important end-point for the chemoprevention of colon carcinogenesis. In this context, the comet assay has been used as a rapid and sensitive tool for detecting primary DNA damage in individual cells. The association of chemical-induced comet and ACF assays can provide information on the mechanisms of action of a candidate drug and help determine in which step of carcinogenesis it acts [16].

\section{Methods}

\section{Plant material and its extraction}

Leaves of Copaifera langsdorffii Desff were collected in Ribeirão Preto, São Paulo, Brazil and identified by Dr. Milton Groppo Junior from Faculdade de Filosofia, Ciências e Letras de Ribeirão Preto, University of São Paulo, Ribeirão Preto, São Paulo, Brazil; a voucher specimen (SPFR 10120) was deposited in the herbarium of the aforementioned institution. Leaves were dried at $40^{\circ} \mathrm{C}$ with air circulation and grounded in a knife mill. The crude hydroalcoholic extract was obtained by macerating $200 \mathrm{~g}$ of the leaves powder in ethanol/water 7:3 three times, every $48 \mathrm{~h}$. The filtered extracts were combined, concentrated under vacuum, and lyophilized, which furnished $38 \mathrm{~g}$ of the extract.

\section{HPLC analysis of the crude hydroalcoholic extract of Copaifera langsdorffii leaves}

HPLC analyses were conducted on an HPLC Shimadzu SCL-10Avp (Kyoto, Japan) multisolvent delivery system equipped with a Shimadzu SPD-M10Avp photodiode array detector and an Intel Celeron computer; two monolithic columns linked in series (Onyx ${ }^{\mathrm{TM}} 100 \mathrm{X} 4.6$ $\mathrm{mm}-\mathrm{C}_{18}$ Phenomenex) and a pre-column from the same company were also used. The mobile phase consisted of water and acetonitrile. The elution program was $5-6 \%$ of acetonitrile in water $(\mathrm{v} / \mathrm{v})$ in the first $\mathrm{mi}-$ nute, followed by $6-8 \%$ (1-2 $\mathrm{min}$.), $8-10 \%(2-5 \mathrm{~min}$.), 10 - 15\% (5 - 12 min.), 15\% (12 - $22 \mathrm{~min}$.), 15 - 25\% (22 - $27 \mathrm{~min}.), 25 \%$ ( 27 - $35 \mathrm{~min}$.), 25 - 40\% (35 - $39 \mathrm{~min}$.), 40\% (39-42 min.), 40 - 100\% (42-47 min.), and 100\% acetonitrile for another minute, at a flow rate of $1.0 \mathrm{~mL}$ $\mathrm{min}^{-1}$; twelve additional minutes were allowed for the column to return to the initial conditions and re-equilibrate. The chromatogram peaks were detected at 257 $\mathrm{nm}$. HPLC-grade solvents were purchased from Tedia Company INC. (Fairfield, OH, USA). Water was purified using the Milli-Q-plus filter system (Millipore, Bedford, MA, USA.). Quercetin-3-O- $\alpha$-L-rhamnopyranoside (quercitrin) and kaempferol-3-O- $\alpha$-L-rhamnopyranoside (K-rham) had been previously isolated in our laboratory.

\section{Animals}

Male Wistar rats aged five weeks and weighing approximately 120 g were obtained from the animal house of the Faculty of Pharmaceutical Sciences of Ribeirão Preto, University of São Paulo (Ribeirão Preto, São Paulo, Brazil) and acclimatized for a period of one week before the beginning of the experiments (week 1). Animals were maintained in a room under controlled conditions of temperature $\left(22 \pm 2^{\circ} \mathrm{C}\right)$, humidity $(50 \pm 10 \%)$, and a 12-h light/dark cycle; standard rat chow and water were available ad libitum. The study protocol was approved by the Ethics Committee for Animal Care of the University of Franca (process no 014/11).

\section{Carcinogen treatments}

The well-known colon carcinogen 1,2-dimethylhydrazine (DMH, Sigma-Aldrich) was dissolved immediately before use in $1 \mathrm{mM}$ EDTA (ethylenediamine tetraacetic acid). For the comet assay, a single DMH dose of $40 \mathrm{mg} / \mathrm{kg}$ ( $\mathrm{kg}$ corresponds to the animal body weight throughout this work) was administered to the animals. For the ACF 
assay, a total DMH dose of $160 \mathrm{mg} / \mathrm{kg}$ divided into four subcutaneous (sc) injections of $40 \mathrm{mg} / \mathrm{kg}$ was administered twice a week for two weeks (weeks 2 and 3), as described by Furtado et al. [17].

\section{Comet assay}

Groups of six animals were distributed as follows: negative control (EDTA, $0.05 \mathrm{~mL} / 10 \mathrm{~g}$, sc); positive control (DMH, $40 \mathrm{mg} / \mathrm{kg}$ ); solvent control (dimethylsulfoxide, DMSO, Sigma-Aldrich, $0.6 \mathrm{~g} / \mathrm{kg}$ ); treated with the $C$. langsdorffii extract $(80 \mathrm{mg} / \mathrm{kg})$; treated with the solvent solution plus DMH; and treated with the C. langsdorffii extract (20,40, and $80 \mathrm{mg} / \mathrm{kg}$ ) plus DMH. The C. langsdorffii doses were selected on the basis of literature data [18]. The extract was dissolved in 14\% DMSO in water; the treatment groups received similar DMSO doses. Animals were treated with the $C$. langsdorffii extract by gavage ( $1 \mathrm{~mL}$ per animal) for seven consecutive days, and injected with $40 \mathrm{mg} / \mathrm{kg} \mathrm{DMH}$ on day 7 . Body weight and water consumption were measured on a daily basis throughout the experimental period. Animals were anesthetized with sodium pentobarbital ( $45 \mathrm{mg} / \mathrm{kg}$; i.p.) and euthanized on day 7, $4 \mathrm{~h}$ after treatment with $\mathrm{DMH}$ or EDTA. After laparotomy, the colon was excised, tied at one extremity, and flushed with saline, to remove feces. The other extremity was tied, too, and an enzymatic cocktail ( $0.3 \mathrm{mg}$ collagenase I + $5 \mathrm{mg}$ trypsin/EDTA) was injected into the colon. Next, the colon containing the enzymatic cocktail was placed into phosphate-buffered saline (PBS) and kept in a water bath at $37^{\circ} \mathrm{C}$ for 40 min; one colon extremity was cut off to collect the cell suspension. Cell viability was determined on portions of the cell suspension using a dual-dye assay based on a combination of acridine orange and ethidium bromide (under a fluorescent microscope, viable cells that metabolize acridine orange appear green). To accomplish this assay, a $20 \mu \mathrm{L}$ aliquot of the dye solution was mixed with $20 \mu \mathrm{L}$ of the cell suspension. Two hundred cells were counted per animal; cells with viability $\geq 80 \%$ were used for the comet assay.

The alkaline comet assay was performed according to Singh et al. [19] and Burlinson et al. [20]. Briefly, $20 \mu \mathrm{L}$ of the colon cell suspension were mixed with $120 \mu \mathrm{L}$ of a $0.5 \%$ low-melting-point agarose and layered on a slide precoated with a thin layer of normal-melting-point agarose. The slides were placed into a lysis solution (2.5 M NaCl, $100 \mathrm{mM}$ EDTA, $10 \mathrm{mM}$ Tris, $1 \%$ sodium laurylsarcosine, $\mathrm{pH} 10$; with $1 \%$ Triton $\mathrm{X}-100$ and $10 \%$ DMSO added just before use) for $24 \mathrm{~h}$. The slides were washed in PBS and placed into a horizontal electrophoresis unit filled with freshly prepared alkaline buffer $(1 \mathrm{mM}$ EDTA and $300 \mathrm{mM} \mathrm{NaOH}, \mathrm{pH}$ 13). After $20 \mathrm{~min}$ of DNA unwinding, electrophoresis was carried out in the same buffer at $25 \mathrm{~V}$ and $300 \mathrm{~mA}$ for $20 \mathrm{~min}$. The slides were neutralized (0.4 M Tris, pH 7.5), fixed with $100 \%$ ethanol, stained with $40 \mu \mathrm{L}$ of SYBR gold (10,000X concentrate in DMSO; $1 \mu \mathrm{L} / 500 \mu \mathrm{L}$ distilled water), and covered with a coverslip. The stained comets were immediately evaluated at $1000 \mathrm{X}$ magnification under a Nikon fluorescence microscope fitted with a 515-560 nm excitation filter and a $590 \mathrm{~nm}$ barrier filter. For each treatment, the extent and distribution of DNA damage indicated by the comet assay were evaluated by examining 100 randomly selected and non-overlapping comets on the slides (i.e., 600 comets per treatment). For each slide, the comets were visually scored and allocated to one of four classes $(0,1,2$, and 3$)$ according to tail size, as follows: class 0 - undamaged and no tail, class 1 - a short tail with length smaller than the diameter of the head (nucleus), class 2 - tail length between one and two times the diameter of the head, and class 3 - maximal damage: a long tail measuring more than twice the diameter of the head (Figure 1). The few comets containing no head and those with almost all DNA in the tail, or with a very wide tail, were excluded from the analysis since they may correspond to dead cells [21]. The total score for 600 comets was calculated according to the modified formula of Manoharan and Banejee [22], as shown below:

$$
\text { score }=\left(\begin{array}{lll}
1 & x & n_{1}
\end{array}\right)+\left(2 x n_{2}\right)+\left(3 x n_{3}\right),
$$

where $n$ is the number of comets in each analyzed class. Thus, the total score ranged from 0 to 600 .

The percent reduction in DMH-induced damage elicited by the $C$. langsdorffii extract was calculated according to Waters et al. [23] using the following formula:

$$
\% \text { Reduction }=\frac{A-B}{A-C} \times 100,
$$

where $A, B$, and $C$ correspond to the mean score obtained for the group treated with DMH (positive control), the C. langsdorffii extract plus DMH, and EDTA (negative control), respectively.

\section{Aberrant crypt foci assay}

Each treatment group consisted of six animals fed with standard chow throughout the experiment (5 weeks). After being acclimatized for one week (week 1), the animals were divided into eight treatment groups: animals treated with $80 \mathrm{mg} / \mathrm{kg}$ C. langsdorffii extract; $\mathrm{DMH}$ (160 mg/kg, positive control); solvent (DMSO; $0.6 \mathrm{~g} / \mathrm{kg}$ ) plus DMH; C. langsdorffii extract (at 20, 40, and $80 \mathrm{mg} / \mathrm{kg}$ ) plus DMH; EDTA (negative control); and DMSO (solvent control). The study period of four weeks was selected on the basis of previous works, which considered four weeks enough to observe ACF formation of $[24,25]$. The negative and positive controls received EDTA $(0.05 \mathrm{~mL} / 10 \mathrm{~g})$ or $\mathrm{DMH}(40 \mathrm{mg} / \mathrm{kg})$, respectively, twice a week for two weeks (weeks 2 and 3). DMH and EDTA were administered by 


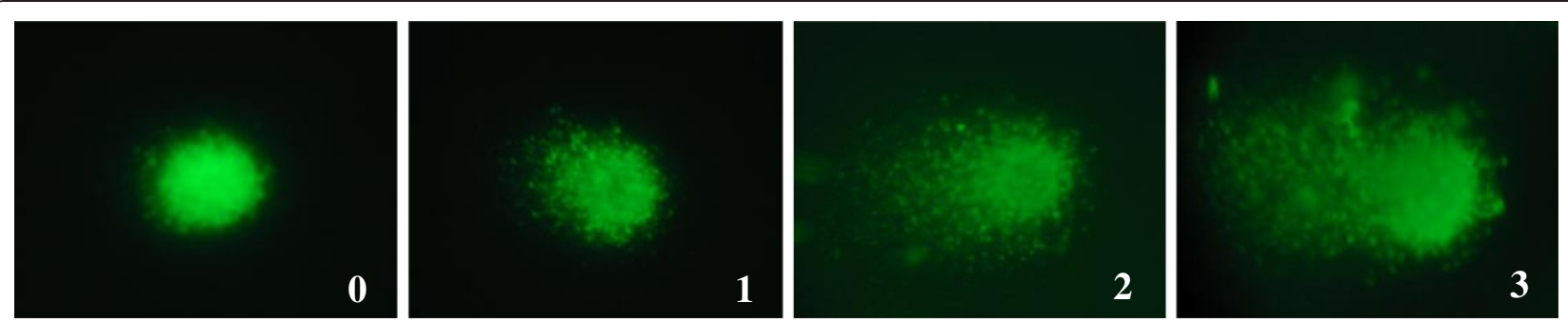

Figure 1 Images of the comets observed for the colon cells of Wistar rats. They represent classes $0-3$ as used for visual scoring (magnification: 1000 X; SYBR gold).

subcutaneous injections. The C. langsdorffii extract and solvent solution were administered to rats five times a week for four weeks (weeks 2 to 5$)$ by gavage $(1 \mathrm{~mL}$ per animal), during and after DMH treatment. Body weight and water consumption were measured five times a week throughout the experimental period. All the animals were anesthetized with sodium pentobarbital ( $45 \mathrm{mg} / \mathrm{kg}$; i.p.) and euthanized at week 5 (four weeks after the first DMH administration). After laparotomy, the distal colon was excised, flushed with $0.9 \%$ saline, cut open along the longitudinal axis, and fixed in 10\% phosphate-buffered formalin $(\mathrm{pH}$ 6.9-7.1) for $24 \mathrm{~h}$. Immediately before analysis, the colon was stained with $0.02 \%$ methylene blue for $5 \mathrm{~min}$, mounted on microscope slides with the mucosal side facing upward, and observed under a light microscope at 100x magnification. Fifty sequential fields of the distal colon were screened for ACF, which were characterized by elongated, slit-shaped lumens surrounded by thickened epithelium that stained more intensely than the surrounding normal crypts [26]. According to Bird and Good [27], aberrant crypt (AC) initially appears in isolation; after some time, ACF with an additional crypt can be observed (Figure 2). The new crypts generally

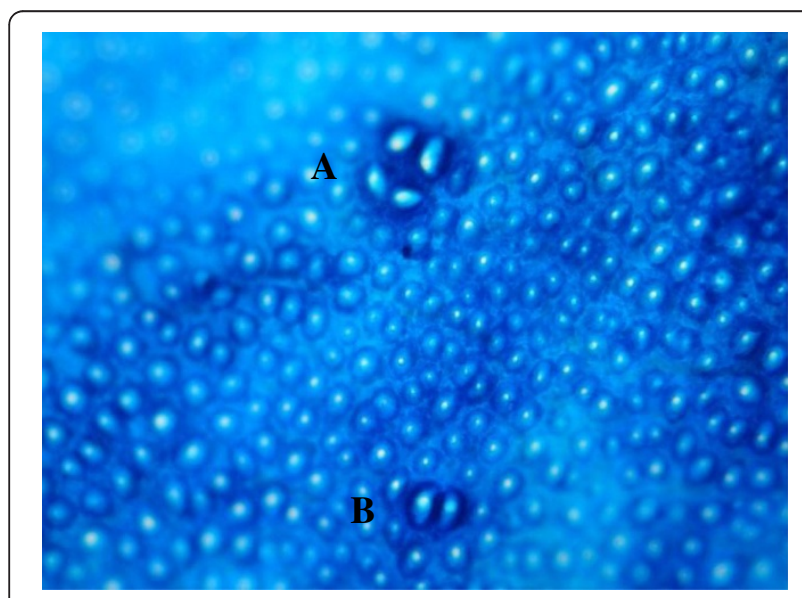

Figure 2 Photomicrograph of methylene blue-stained, wholemount preparations of colon of Wistar rats treated with DMH with ACF containing four (A) and two (B) aberrant crypts/focus. derive from previously formed AC. Thus, the number of crypts per ACF, called the "multiplicity of crypts", is an important parameter to evaluate ACF progression [28]. Each colon specimen was examined by at least three observers in a double-blind manner.

\section{Statistical analysis}

All the data were analyzed statistically by analysis of variance for completely randomized experiments, with calculation of the $\mathrm{F}$ statistics and respective $\mathrm{p}$ values. In cases in which $P<0.05$, treatment means were compared by the Tukey test, and the minimum significant difference was calculated for $\alpha=0.05$.

\section{Results}

The HPLC analysis of the hydroalcoholic extract of $C$. langsdorffii leaves allowed us to quantify the flavonols quercetin-3-O- $\alpha$-L-rhamnopyranoside 1 and kaempferol-3-O- $\alpha$-L-rhamnopyranoside 2 as major compounds (Figure 3).

Regarding the biological assays, Tables 1 and 2 contain the means of the final body weight, body weight gain, and water consumption of the animals during the experimental period. The groups did not differ in terms of these variables.

The comet assay did not reveal any significant differences between animals treated with the $C$. langsdorffii extract only $(80 \mathrm{mg} / \mathrm{kg})$ and the negative control group (receiving EDTA only, $P>0.05$ ), showing that the extract does not display genotoxicity (Table 3). The extent of DNA damage was significantly higher for the group receiving DMH only (positive control) as compared with the negative control. Animals treated with different doses of the $C$. langsdorffii extract combined with DMH had significantly less DNA damage as compared with the positive control - DNA damage decreased between $14.3 \%$ and $38.8 \%$, with the C. langsdorffii extract exerting a non-significant dose-dependent protective effect. Animals treated with the solvent solution plus DMH and the positive control did not differ with respect to DNA damage. Cell viability was higher than $95 \%$ for all the treatment groups. 

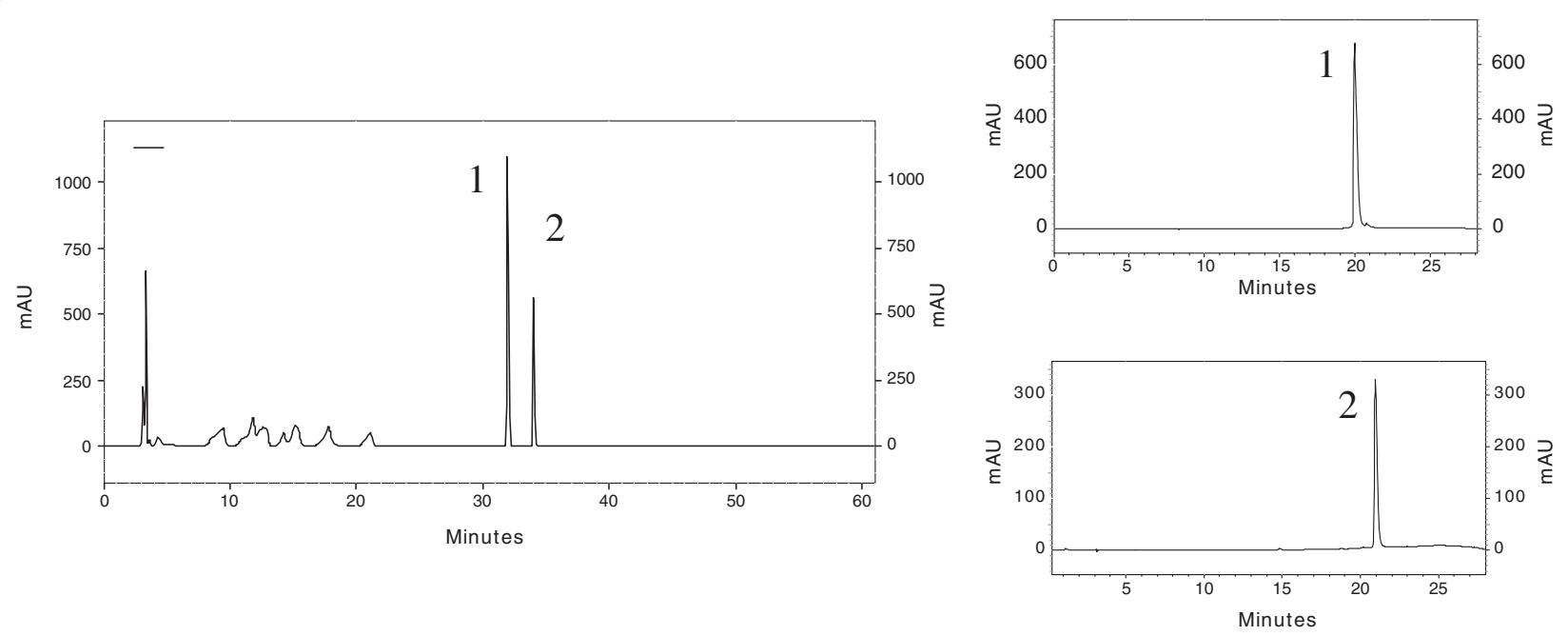

Figure $3 \mathrm{~A}$, B and C Chromatographic profile of the hydroalcoholic extract of the leaves of C. langsdorffii at $257 \mathrm{~nm}(\mathrm{~A})$; Chromatogram of the standard quercetin-3-O- $a$-L-rhamnopyranoside 1 (B); Chromatogram of the standard kaempferol-3-O- $\alpha$-Lrhamnopyranoside 2 (C).

No ACF were observed in the negative control and in the groups receiving $C$. langsdorffii extract $(80 \mathrm{mg} / \mathrm{kg})$ or DMSO (data not shown), but only in DMH-treated rats. The number of ACF and the number of AC were significantly lower in the groups treated with 40 and $80 \mathrm{mg} / \mathrm{kg} \mathrm{C}$. langsdorffii extract during and after $\mathrm{DMH}$ treatment as compared with the group treated with DMH only (Table 4). The results for the animals treated with DMSO plus $\mathrm{DMH}$ did not differ significantly from those obtained for the animals treated with $\mathrm{DMH}$. The number of $\mathrm{AC}$ and the AC/ACF ratio obtained for all the groups treated with $\mathrm{DMH}$ revealed higher frequency of foci with one crypt.

Table 1 Final body weight, body weight gain, and water consumption of rats treated with different doses of the C. langsdorffii extract and/or DMH and their respective controls, for the comet assay

\begin{tabular}{lccc}
\hline $\begin{array}{l}\text { Treatments } \\
(\mathbf{m g} / \mathbf{k g})\end{array}$ & $\begin{array}{c}\text { Final body } \\
\text { weight }(\mathbf{g})^{*}\end{array}$ & $\begin{array}{c}\text { Body weight } \\
\text { gain }(\mathbf{g})^{*}\end{array}$ & $\begin{array}{c}\text { Water } \\
\text { consumption }\end{array}$ \\
\hline EDTA & $166.8 \pm 11.6$ & $54.5 \pm 7.9$ & $36.9 \pm 5.6$ \\
DMSO & $170.6 \pm 11.0$ & $51.1 \pm 6.3$ & $41.5 \pm 4.7$ \\
80 & $167.5 \pm 11.0$ & $54.6 \pm 5.8$ & $40.6 \pm 7.4$ \\
DMH & $165.0 \pm 11.3$ & $52.6 \pm 7.4$ & $37.2 \pm 6.5$ \\
DMSO + DMH & $168.1 \pm 10.4$ & $56.6 \pm 7.6$ & $44.6 \pm 12.3$ \\
$20+D M H$ & $167.1 \pm 11.4$ & $52.3 \pm 9.3$ & $37.9 \pm 5.8$ \\
$40+D M H$ & $168.1 \pm 11.3$ & $49.3 \pm 6.3$ & $37.5 \pm 6.8$ \\
$80+D M H$ & $169.6 \pm 10.2$ & $53.3 \pm 6.9$ & $45.5 \pm 7.2$ \\
\hline
\end{tabular}

EDTA, vehicle control; $D M H, 1,2$-dimethylhydrazine (40 mg/kg); DMSO, dimethylsulfoxide $(0.6 \mathrm{~g} / \mathrm{kg})$. The numbers 20,40 , and 80 correspond to the extract dose in $\mathrm{mg} / \mathrm{kg}$.

*Values are the mean \pm standard deviation.

a Water consumption calculated in $\mathrm{mL}$ per animal per day.

\section{Discussion}

Because colorectal cancer is an important cause of death in many countries, we evaluated the effect of the hydroalcoholic extract of $C$. langsdorffii leaves on this neoplasia. The sequence of events that culminates in colon cancer helped us select the bioassays and protocols for this study. We employed the two endpoints-chemical-induced DNA damage and ACF - because they help determine in which step of colon carcinogenesis the C. langsdorffii extract acts.

ACF are putative preneoplastic lesions of colonic neoplasia in rodents and humans [29]; they are useful

Table 2 Final body weight, body weight gain, and water consumption of rats treated with different doses of the C. langsdorffii extract and/or DMH and their respective controls, for the aberrant crypt foci (ACF) assay

\begin{tabular}{lccc}
\hline $\begin{array}{l}\text { Treatments } \\
\text { (mg/kg) }\end{array}$ & $\begin{array}{c}\text { Final body } \\
\text { weight } \mathbf{( g )}\end{array}$ & $\begin{array}{c}\text { Body weight } \\
\text { gain }(\mathbf{g})^{*}\end{array}$ & $\begin{array}{c}\text { Water } \\
\text { consumption }\end{array}$ \\
\hline EDTA & $326.8 \pm 12.5$ & $215.6 \pm 11.9$ & $37.5 \pm 6.8$ \\
DMSO & $335.6 \pm 11.2$ & $214.5 \pm 11.7$ & $37.5 \pm 4.4$ \\
80 & $325.5 \pm 12.8$ & $219.0 \pm 11.5$ & $37.5 \pm 6.8$ \\
DMH & $321.8 \pm 10.1$ & $222.5 \pm 10.7$ & $37.9 \pm 5.8$ \\
DMSO + DMH & $334.3 \pm 11.3$ & $223.5 \pm 11.0$ & $45.5 \pm 7.2$ \\
$20+$ DMH & $334.5 \pm 10.9$ & $224.3 \pm 10.8$ & $37.2 \pm 6.5$ \\
$40+$ DMH & $341.8 \pm 11.5$ & $221.8 \pm 11.1$ & $44.6 \pm 12.3$ \\
$80+$ DMH & $340.5 \pm 12.1$ & $225.5 \pm 11.8$ & $55.0 \pm 18.7$ \\
\hline
\end{tabular}

$E D T A$, vehicle control; $D M H, 1,2$-dimethylhydrazine ( $160 \mathrm{mg} / \mathrm{kg}) ; D M S O$, dimethylsulfoxide $(0.6 \mathrm{~g} / \mathrm{kg})$. The numbers 20,40 , and 80 correspond to the extract dose in $\mathrm{mg} / \mathrm{kg}$.

*Values are the mean \pm standard deviation.

${ }^{a}$ Water consumption calculated in $\mathrm{mL}$ per animal per day. 
Table 3 DNA migration in the comet assay observed in Wistar rat colon treated with different doses of the C. langsdorffii extract and/or DMH and their respective controls

\begin{tabular}{|c|c|c|c|c|c|c|}
\hline \multirow{2}{*}{$\begin{array}{l}\text { Treatments } \\
(\mathrm{mg} / \mathrm{kg})\end{array}$} & \multicolumn{4}{|c|}{ Comet class* } & \multirow[t]{2}{*}{ *Score } & \multirow{2}{*}{$\frac{\text { Reduction }}{(\%)}$} \\
\hline & 0 & 1 & 2 & 3 & & \\
\hline Control & $66.2 \pm 4.3$ & $23.2 \pm 5.7$ & $7.3 \pm 2.3$ & $3.3 \pm 1.8$ & $47.8 \pm 6.4$ & - \\
\hline DMSO & $65.3 \pm 3.9$ & $21.2 \pm 4.4$ & $8.3 \pm 2.4$ & $3.7 \pm 2.2$ & $48.8 \pm 4.8$ & - \\
\hline 80 & $79.7 \pm 5.1$ & $14.7 \pm 6.3$ & $5.0 \pm 2.6$ & $0.7 \pm 0.8$ & $26.7 \pm 6.0$ & - \\
\hline $\mathrm{DMH}$ & $13.2 \pm 2.1$ & $26.2 \pm 5.3$ & $33.5 \pm 5.2$ & $27.3 \pm 3.7$ & $175.2 \pm 9.6^{a}$ & - \\
\hline $\mathrm{DMSO}+\mathrm{DMH}$ & $11.5 \pm 1.6$ & $23.8 \pm 9.5$ & $32.8 \pm 8.3$ & $28.7 \pm 4.3$ & $175.5 \pm 11.7^{a}$ & - \\
\hline $20+\mathrm{DMH}$ & $10.8 \pm 4.5$ & $40.2 \pm 3.6$ & $25.0 \pm 6.4$ & $22.3 \pm 4.3$ & $157.2 \pm 12.2^{a, b}$ & 14.3 \\
\hline $40+\mathrm{DMH}$ & $19.3 \pm 6.3$ & $34.0 \pm 4.3$ & $29.7 \pm 3.6$ & $16.8 \pm 5.9$ & $143.8 \pm 15.1^{a, b}$ & 24.7 \\
\hline $80+\mathrm{DMH}$ & $23.3 \pm 6.9$ & $40.8 \pm 7.1$ & $20.8 \pm 3.5$ & $15.0 \pm 5.9$ & $125.8 \pm 12.7^{a, b, c}$ & 38.8 \\
\hline
\end{tabular}

A total of 600 cells were examined per treatment; $D M H, 1,2$-dimethylhydrazine (40 mg/kg). The numbers 20,40 , and 80 correspond to the extract dose in mg/kg. *Values are the mean \pm standard deviation.

${ }^{a}$ Significantly different from the control $(P<0.05)$.

${ }^{\text {bS }}$ ignificantly different from the DMH group $(P<0.05)$.

'Significantly different from the $20+$ DMH group $(P<0.05)$.

intermediate biomarkers that help one to assess the modifying effects of certain natural and synthetic compounds on chemically induced carcinogenesis [30]. The advantage of studying the pathogenesis of cancer of the colon in animal models induced by chemical carcinogens, is that the tumor induction is rapid and allows to reproduce the adenoma-carcinoma sequence, as in humans. The high frequency of tumors that develop in the distal colon of rats, and the histogenesis of multiple adenomas, with consequent formation of adenocarcinomas, justify the importance of this species in the study of the pathogenesis of colon cancer [31].

Treatment with the $C$. langsdorffii extract reduced DNA damage and the number of ACF in the colon tissue of DMH-treated rats. ACF appear to arise from gene mutations, so an increased number of ACF reflects the initiation step of colorectal carcinogenesis. Our results indicate that the $C$. langsdorffii extract prevents the DNA damage and formation of preneoplastic lesions involved in the initial phase of colon cancer. In a previous study, treatments with $C$. langsdorffii extract diminished the genotoxicity induced by the chemotherapeutic agent doxorubicin as revealed by the Swiss mice peripheral blood micronucleus test [18].

In vivo studies have shown that $\mathrm{DMH}$ is metabolized to azomethane, azoxymethane, methylazoxymethanol, ethane, and carbon dioxide [32]. Furthermore, DMH has been reported to induce carcinogenesis in rats and mice due to the high production of reactive free radicals [33,34], which react with DNA, thus demonstrating its genotoxic effect. Although the mechanisms underlying the protective effect against DNA damage and ACF induction are not clearly understood, the putative antioxidant activity of the $C$. langsdorffii extract might explain its inhibitory action at least in part.

Phenolic compounds display antioxidant activity as a result of their capacity to scavenge free radicals [35]. The most important natural phenolics are flavonoids, which present a broad spectrum of chemical and biological activities, including antioxidant and free radical

Table 4 Mean number ( \pm SD) of aberrant crypt foci (ACF) and aberrant crypt $(A C)$ observed in the distal colon of rats treated with the C. langsdorffii extract and DMH

\begin{tabular}{|c|c|c|c|c|c|c|c|}
\hline \multirow{2}{*}{$\begin{array}{l}\text { Treatments } \\
(\mathrm{mg} / \mathrm{kg})\end{array}$} & \multicolumn{4}{|c|}{ Number of ACF } & \multirow{2}{*}{$\begin{array}{l}\text { Number } \\
\text { of ACF }\end{array}$} & \multirow{2}{*}{$\begin{array}{l}\text { Number } \\
\text { of } A C\end{array}$} & \multirow{2}{*}{$\begin{array}{l}\mathrm{AC} / \\
\mathrm{ACF}\end{array}$} \\
\hline & 1 & 2 & 3 & 4 & & & \\
\hline $\mathrm{DMH}$ & $9.2 \pm 1.2$ & $3.2 \pm 1.3$ & $1.2 \pm 0.9$ & $0.5 \pm 0.8$ & $14.0 \pm 1.4$ & $20.8 \pm 1.9$ & $1.5 \pm 0.1$ \\
\hline $\mathrm{DMSO}+\mathrm{DMH}$ & $6.7 \pm 2.6$ & $3.5 \pm 1.9$ & $2.2 \pm 1.5$ & $0.3 \pm 0.8$ & $12.8 \pm 3.5$ & $21.0 \pm 5.9$ & $1.6 \pm 0.2$ \\
\hline $20+\mathrm{DMH}$ & $7.2 \pm 1.6$ & $4.8 \pm 1.7$ & $2.2 \pm 0.8$ & $0.2 \pm 0.4$ & $14.3 \pm 2.7^{b}$ & $23.7 \pm 5.3^{b}$ & $1.6 \pm 0.2$ \\
\hline $40+\mathrm{DMH}$ & $6.2 \pm 2.3$ & $4.0 \pm 0.7$ & 0 & $0.4 \pm 0.5$ & $10.6 \pm 1.9^{\mathrm{a}}$ & $15.8 \pm 2.9^{\mathrm{a}}$ & $1.5 \pm 0.2$ \\
\hline $80+\mathrm{DMH}$ & $4.7 \pm 0.8$ & $2.7 \pm 1.2$ & $0.7 \pm 0.8$ & $0.2 \pm 0.4$ & $8.0 \pm 1.9^{a}$ & $12.0 \pm 4.0^{\mathrm{a}}$ & $1.5 \pm 0.2$ \\
\hline
\end{tabular}

$D M H, 1,2$-dimethylhydrazine $(160 \mathrm{mg} / \mathrm{kg}) ; D M S O$, dimethylsulfoxide $(0.6 \mathrm{~g} / \mathrm{kg})$. The numbers 20,40 , and 80 correspond to the extract dose in $\mathrm{g} / \mathrm{kg}$.

*Values are the mean \pm standard deviation.

${ }^{a}$ Significantly different from the DMH group $(P<0.05)$.

${ }^{\mathrm{b}}$ Significantly different from the $40+\mathrm{DMH}$ and $80+\mathrm{DMH}$ groups $(P<0.05)$. 
scavenging properties. Flavonoids act as antioxidants, scavengers of a wide range of reactive oxygen species, and inhibitors of lipid peroxidation [36].

The hydroalcoholic extract of $C$. langsdorffii leaves contains the flavonoids quercetin-3-O- $\alpha$-L-rhamnopyranoside and kaempferol-3-O- $\alpha$-L-rhamnopyranoside as major compounds; these flavonoids constitute about $10 \%$ of the crude extract (Figure 3). The high water solubility of this extract facilitates its dissolution in the gastrointestinal tract, enhancing its antioxidant potential. Studies using a model system for food products have demonstrated that flavonoids such as quercetin, rhamnetin, kaempferol, rutin, and quercetrin are one of the most effective antioxidants [37].

Serpeloni et al. [38] stated that studying the chemical constituents of plants and their mechanisms of action is a major challenge: plant species contain various compounds, and their extracts can produce biological effects that may arise from the combined effects of the individual compounds. Phytochemical screening considers that every compound, regardless of their proportion in the plant, known or not, may be an active ingredient [39]. Studies suggest that combinations of phenolics naturally present in fruits and vegetables as a whole inhibit cancer cell growth more effectively than the individual compounds [40].

Flavonoids and other phenolic compounds might exert direct protective effects on the gastrointestinal tract, by scavenging reactive species and/or preventing their formation. Polyphenols can inhibit hemeprotein-induced peroxidation in the stomach and decrease DNA base deamination or nitrosamine formation by $\mathrm{HNO}_{2}$-derived reactive nitrogen species [41].

\section{Conclusion}

Our results indicate that the hydroalcoholic extract of $C$. langsdorffii leaves acts as a chemopreventive agent in the rat-DMH colon cancer model. C. langsdorffii extract supplementation inhibited DMH-induced DNA damage and ACF formation. Although the mechanism through which the C. langsdorffii extract acts in this colon cancer model is unclear, this extract is a promising candidate for the prevention of various types of cancer. Further investigations using in vitro assays to elucidate the mechanisms of action of the C. langsdorffii extract are desirable before it is used as a chemopreventive agent in humans.

\section{Competing interest}

The authors declare that they have no competing interests.

\section{Authors' contributions}

$\mathrm{J}$, and E carried out the comet and ACF assays. R and I carried out HPLC analysis of the crude hydroalcoholic extract of Copaifera langsdorffii. D conceived the study, participated in its design, coordinated, and helped draft the manuscript. All the authors read and approved the final manuscript.

\section{Acknowledgement}

This study was supported by Fundação de Amparo à Pesquisa do Estado de São Paulo (FAPESP, grants number 2008/57775-6 and 2011/13630-7), Brazil. JM Senedese received a CNPq fellowship (Conselho Nacional de

Desenvolvimento Científico e Tecnológico, Brazil).

\section{Author details}

${ }^{1}$ Avenida Dr. Armando Salles de Oliveira, Universidade de Franca, 201 Parque Universitário, Franca, São Paulo 14404-600, Brazil. Faculdade de Ciências Farmacêuticas de Ribeirão Preto, Universidade de São Paulo, Avenida do Café S/N, Ribeirão Preto, São Paulo 14040-903, Brazil.

Received: 16 August 2012 Accepted: 19 December 2012

Published: 7 January 2013

\section{References}

1. Clarke JM, Young GP, Topping DV, Bird AR, Cobiac L, Scherer BL, Winkler JG, Lockett TJ: Butyrate delivered by butyrylated starch increases distal colonic epithelial apoptosis in carcinogen-treated rats. Carcinogens 2012, 33:197-202.

2. Barone M, Lofano K, De Tullio N, Licino R, Albano F, Di Leo A: Dietary, endocrine, and metabolic factors in the development of colorectal cancer. J Gastrointest Cancer 2012, 43:13-19.

3. Kyung Sung M, Jee-Young Yeon J, Shin-Young P, Jung Han YP, Myung-Sook C: Obesity-induced metabolic stresses in breast and colon cancer. Ann N Y Acad Sci 2011, 1229:61-68.

4. Gourineni VP, Verghese M, Boateng J, Shackelford L, Bhat KN: Chemopreventive potential of synergy 1 and soybean in reducing azoxymethane-induced aberrant crypt Foci in Fisher 344 male rats. J Nutr Metab 2011, 983038:8.

5. Brandão HM, Juceni P, David JP, Couto RD, Nascimento JAP, David JM: Química e farmacologia de quimioterápicos antineoplásicos derivados de plantas. Quim Nova 2010, 33:1359-1369.

6. Santos AO, Ueda-Nakamura T, Filho BPD, Veiga VF Jr, Pinto ACD, Nakamura CV: Effect of Brazilian copaiba oils on Leishmania amazonensis. J Ethnopharmacol 2008, 120:204-208.

7. Gomes MM, Rezende CM, Fontes SP, Matheus MF, Fernandes PD: Antinociceptive activity of Amazonian copaiba oil. J Ethnopharmacol 2007, 109:486-492.

8. Carvalho JCT, Cascon V, Possebon LS, Morimoto MSS, Cardoso LGV, Kaplan MAC, Gilbert B: Topical anti-inflammatory and analgesic activities of Copaifera duckei Dwyer. Phytother Res 2005, 19:946-950.

9. Somova LI, Shodem FO, Moodley K, Goender Y: Cardiovascular and diuretic activity of kaurene derivatives of Xylopia thiopica and Alepidea amatymbica. J Ethnopharmacol 2001, 77:165-174.

10. Paiva LAF, Gurgel LA, Silva RM, Tome AR, Gramosa NV, Silveira ER, Santos FA, Rao VSN: Anti-inflammatory effect of kaurenoic acid, a diterpene from Copaifera langsdorffii on acetic acid-induced colitis in rats. Vasc Pharmacol 2003, 39:303-307.

11. Oshaki A, Yan LT, Shigeru I, Edatsugi H, Iwata D, Komoda Y: The isolation and in vivo potent antitumor activity of clerodane diterpenoids from the oleoresin of Brazilian medicinal plant Copaifera langsdorffii desfon. Bioorg Med Chem Lett 1994, 4:2889-2892.

12. Paiva LAF, Rao VSN, Gramosa NV, Silveira ER: Gastroprotective effect of Copaifera langsdorffii oleo-resin on experimental gastric ulcer models in rats. J Ethnopharmacol 1998, 62:73-78.

13. Paiva $L A F$, Gurgel $L A$, Campos AR, Silveira ER, Rao VSO: Attenuation of ischemia/reperfusion-induced intestinal injury by oleo-resin from Copaifera langsdorffii in rats. Life Sci 2004, 75:1979-1987.

14. Lee SJ, Lim KT: Inhibitory effect of phytoglycoprotein on tumor necrosis factor-a and interleukin- 6 at initiation stage of colon cancer in 1,2dimethylhydrazine-treated ICR mice. Toxicol Appl Pharmacol 2007, 255:198-205.

15. DMcLellan EA, Bird RP: Aberrant crypts: potential preneoplastic lesions in the murine colon. Cancer Res 1988, 48:6187-6192.

16. Agner AR, Bazo AP, Salvadori DMF, Ribeiro LR: DNA damage and aberrant crypt foci as putative biomarkers to evaluate the chemopreventive effect of annatto (Bixa orellana L.) in rat colon carcinogenesis. Mutat Res 2005, 582:146-154.

17. Furtado RA, Rodrigues EP, Araújo FRR, Oliveira WL, Furtado MA, Castro MB, Cunha WR, Tavares DC: Ursolic acid and oleanoic acid suppress 
preneoplasic lesions induced by 1, 2-dimethylhydrazine in rat colon. Toxicol Pathol 2008, 36:576-580

18. Alves JM, Munari CC, Monteiro Neto MAB, Furtado RA, Senedese JM, Bastos JK, Tavares DC: In vivo protective effect of Copaifera langsdorffii hydroalcoholic extract on micronuclei induction by doxorubicin. J App/ Toxicol 2012, do:10.1002/jat.2777 [Epub ahead of print].

19. Singh NP, McCoy MT, Tice RR, Schneider EL: A simple technique for quantification of low levels of DNA damage in individual cells. Exp Cell Res 1988, 175:184-191.

20. Burlinson B, Tice RR, Speit G, Agurell E, Brendler-Schwaab SY, Collins AR, Escobar P, Honma M, Kumaravel TS, Nakajima M, Sasaki YF, Thybaud V, Uno $Y$, Vasquez M, Hartmann A: Fourth international workgroup on genotoxicity testing: results of the in vivo comet assay workgroup. Mutat Res 2007, 627:31-35.

21. Hartmann A, Speit G: The contribution of cytotoxicity of edible mushroom in a histidine-independent bacterial test system. Food Chem Toxicol 1997, 29:159-165.

22. Manoharan K, Banerjee MR: $\beta$-Carotene reduces sister chromatid exchanges induced by chemical carcinogens in mouse mammary cells in organ culture. Cell Biol Int Rep 1985, 9:783-789.

23. Waters MD, Brady AL, Brockman HE: Antimutagenicity profiles for some model compounds. Mutat Res 1999, 238:57-85.

24. Bazo AP, Rodrigues MAM, Sforcin JM, Camargo JL, Ribeiro LR, Salvadori DMF: Protective action of propolis on the rat colon carcinogenesis. Teratog Carcinog Mutagen 2002, 22:183-194.

25. Rodrigues MAM, Silva LGA, Salvadori DMF, Camargo JLV, Monteiro MR: Aberrant crypt foci colon cancer: comparison between a short-and medium-term bioassay for colon carcinogenesis using dimetylhydrazine in Wistar rats. Braz J Med Biol Res 2002, 35:351-355.

26. Bird RP: Observation and qualification of aberrant crypts in the murine colon treated with a colon carcinogen: preliminary findings. Cancer Lett 1987, 37:147-151.

27. Bird RP, Good CK: The significance of aberrant crypt foci in understanding the pathogenesis of colon cancer. Toxicol Lett 2002, 112-113:395-402.

28. Cheng L, Lai MD: Aberrant crypt foci as microscopic precursors of colorectal cancer. World J Gastroenterol 2003, 9:2642-2649.

29. Baskar AA, Ignacimuthu S, Paulraj GM, Numair KSA: Chemopreventive potential of $\beta$-sitosterol in experimental colon cancer model - an in vitro and in vivo study. BMC Complement Altern Med 2010, 10:1-10.

30. Kumar VK, Vennila S, Nalini N: Modifying effects of morim on the development of aberrant crypt foci and bacterial enzymes in experimental colon cancer. Food Chem Toxicol 2009, 47:309-315.

31. Rosenberg DW, Giardina C, Tanaka T: Mouse models for the study of colon carcinogenesis. Carcinogenesis 2009, 30:183-196.

32. Swenberg JA, Cooper HK, Bucheler J, Kleihues P: 1,2 dimethlhydrazineinduced methylation of DNA bases in various rat organs and the effect of pretreatment with disulfiran. Cancer Res 1979, 39(2 Pt 1):465-467.

33. Tomasi A, Albano E, Botti B, Vannini V: Detection of free radical intermediates in the oxidative metabolism of carcinogenic hydrazine derivates. Toxicol Pathol 1987, 15:178-183.

34. Salim AS: The permissive role of oxygen-derived free radicals in the development of colonic cancer in the rat: a new theory for carcinogenesis. Int J Cancer 1993, 53:1031-1035.

35. Seyoum A, Asres K, El-Fiky FK: Structure-radical scavenging activity relationships of flavonoids. Phytochemistry 2006, 67:2058-2070

36. Ammar RB, Bhouri W, Sghaier BM, Boubaker J, Skandrani I, Neffati A, Bouhlel I, Kilani S, Mariotte AM, Chekir-Ghedira L, Dijoux-Franca MG, Ghedira K: Antioxidant and free radical-scavenging properties of three flavonoids isolated from the leaves of Rhamnus alaternus L. (Rhamnaceae): A structure-activity relationship study. Food Chem Toxicol 2009, 116:258-264.

37. Kanakis CD, Nafisi S, Rajabi M, Shadaloi A, Tarantilis PA, Polissiou MG, Bariyanga J, Tajmir-Riahi HÁ: Structural analysis of DNA and RNA interactions with antioxidant flavonoids. Spectroscopy 2009, 23:29-43.

38. Serpeloni JM, Reis MB, Rodrigues J, Santos LC, Vilegas W, Varanda EA, Dokkedal AL, Colus IM: In vivo assessment of DNA damage and protective effects of extracts from Miconia species using the comet assay and micronucleus test. Mutagenesis 2008, 23:501-507.

39. Yunes RA, Pedrosa RC, Cechinel FV: Fármacos e fitoterápicos: a necessidade do desenvolvimento da indústria de fitoterápicos e fitofármacos no Brasil. Quím Nova 2001, 24:147-152.
40. Campbell JK, King JL, Harmston M, Lila MA, Erdman JW Jr: Synergistic effects of flavonoids on cell proliferation in Hepa-1c1c7 and LNCaP cancer cell lines. J Food Sci 2006, 71:358-363.

41. Halliwell B: Dietary polyphenols: good, bad, or indifferent for your health? Cardiovasc Res 2007, 73:341-347.

doi:10.1186/1472-6882-13-3

Cite this article as: Senedese et al:: Chemopreventive effect of Copaifera langsdorffii leaves hydroalcoholic extract on 1,2-dimethylhydrazine-induced DNA damage and preneoplastic lesions in rat colon. BMC Complementary and Alternative Medicine 2013 13:3.

\section{Submit your next manuscript to BioMed Central and take full advantage of:}

- Convenient online submission

- Thorough peer review

- No space constraints or color figure charges

- Immediate publication on acceptance

- Inclusion in PubMed, CAS, Scopus and Google Scholar

- Research which is freely available for redistribution 